\title{
Sexual dimorphism in growth pattern among the infants with respect to weight during the first year of life: A longitudinal study
}

\author{
Nirmalya Kumar Sinha ${ }^{1}$, *Prabodh Chandra Mondal ${ }^{2}$, Juthika Bhuniya ${ }^{1}$, Dhruba Kumar Mahata ${ }^{2}$, \\ Rincy Mathew ${ }^{2}$
}

Sri Lanka Journal of Child Health, 2021; 50(1): 124-133

\begin{abstract}
Background: The nutritional status of the infants is an important indicator to study the health and nutritional status of the population.
\end{abstract}

Objectives: To study the growth pattern during infancy and to find out the causative factors for growth faltering among infants living in the rural areas of Paschim Medinipur district.

Method: This community based longitudinal study was carried out from 2016-2018 in the rural villages of Kankabati Grampanchayat. Singleton live born babies, born during the first six months of the study period, and belonging to the low socioeconomic status, were included in this study. Multiple births, neonates with major congenital malformations and severe birth asphyxia, that might be associated with growth faltering of infants, were excluded from the study. The estimated sample size was 132. A pre-tested and semi-structured questionnaire, based on demographic information, anthropometric data and history of morbidity, was prepared to collect information of each infant from the mothers/ caregivers. The birth weight of each infant was recorded from hospital discharge certificate. Subsequently, body weight was recorded every $30 \pm 2$ days from the first month of life and thereafter longitudinally throughout infancy.

Results: A total of 164 infants was included. The study showed that when the infants reached the age of 8 months, prevalence of underweight was 'high' (20-29\%). Infants during the period of 9-12 months had 'very high' prevalence of underweight

${ }^{1}$ Raja Narendra Lal Khan Women's College (Autonomous), India, ${ }^{2}$ Midnapore Medical College and Hospital, India

*Correspondence: pcmondal.mmc@gmail.com

iD https://orcid.org/0000-0001-8940-5466

(Keceived on 09 April 2020: Accepted after revision on 22 May 2020)

The authors declare that there are no conflicts of interest

Personal funding was used for the project.

Open Access Article published under the Creative

Commons Attribution CC-BY (C) (i) License $(\geq 30 \%)$. The binary regression analysis indicated that the sex of the neonate (Wald $=4.178 ; \mathrm{p}<0.05$ ) was the more important predictor of underweight at 12 months of age than the birth weight (Wald $=0.351 ; \mathrm{P}>0.05$ ).

Conclusions: This longitudinal study on the weight pattern of the infants up to 12 months of age suggests that the male infants are likely to be underweight when they are nine months of age.

DOI: http://dx.doi.org/10.4038/sljch.v50i1.9414

(Key words: Child health, LBW babies, growth pattern, child nutrition, sexual dimorphism)

\section{Introduction}

Growth pattern in infancy is important from the public health view point in both developing and developed countries ${ }^{1}$. Research in developing countries has mainly focused on the causation of slow growth patterns like low birth weight (LBW), maternal malnutrition, infant morbidity and incorrect weaning practices ${ }^{2-6}$. Child growth is an important indicator of assessing nutritional adequacy, health and development of children, and of estimating the overall nutritional and health status of the population ${ }^{7}$. There are only a few studies carried out in this area focusing on growth pattern during infancy ${ }^{7,8}$. However, the sexual dimorphism in the growth pattern and nutritional status of the rural infants has not been documented in a longitudinal study. Sarkar et al also suggested the need of a similar study in this locality ${ }^{7}$.

\section{Objectives}

To study the growth pattern during infancy and to find out the causative factors for growth faltering among infants living in the rural areas of Paschim Medinipur district.

\section{Method}

This community based longitudinal study was carried out from 2016-2018 in the rural villages of Kankabati Grampanchayat in Paschim Medinipur District, West Bengal, 23 metres above the sealevel and about $127 \mathrm{~km}$ away from Kolkata city. Singleton live born babies born during the first six months of the study period and belonging to the low socioeconomic status were included in the study. Multiple births, neonates with major 
congenital malformations and severe birth asphyxia, that might be associated with growth faltering of the infants, were excluded from study.

Sample size: The minimum estimated sample size was calculated using the standard formula: $n=$ $\left(\mathrm{z}^{2} \mathrm{pq}\right) / \mathrm{d}^{2}$. The calculation $\left(\left(1.96^{2} \times 0.328 \times 0.672\right) /\right.$ $\left.\left(0.08^{2}\right)\right)$ was based on $32.8 \%$ prevalence $(p)$ of underweight at the age of 12-17 months (as that was the highest among all the categories viz. $<6,6-$ 8, 9-11 months) according to the recent report of the fourth National Family Health Study (NFHS-4) conducted during 2015-2016 in India ${ }^{9}$, where $\mathrm{z}=1.96, \mathrm{q}=\mathrm{p}-1$ and desired precision (d) was $\pm 8 \% \mathbf{0}$. Thus, the estimated sample size was 132 and with a dropout rate of $20 \%$ was 159 .

Anthropometric assessment: A pre-tested, semistructured questionnaire, based on demographic information, anthropometric data and history of morbidity, was prepared to collect data of each infant from the mothers/caregivers. Infants were identified by name, age and sex. Date of birth was noted from hospital records. Anthropometric data, including weight of neonates, were measured using standard techniques ${ }^{11}$. Birth weight of each infant was recorded from hospital discharge certificate. Both LBW babies $(<2500 \mathrm{~g})$ and normal birth weight (NBW) babies $(\geq 2500 \mathrm{gm})$ were included in study. Subsequently, the body weight was recorded every $30 \pm 2$ days from the first month of life and thereafter longitudinally throughout infancy. Weight was measured by a digital scale and recorded to the nearest $0.01 \mathrm{~kg}$. During weight measurement asepsis was maintained. All observations were made by visiting the families at home. If the respondent was not contactable during the visit, three consecutive visits were made in order to avoid dropouts.

The nutritional status of the infants was evaluated using age and sex specific values of weight from the National Centre for Health Statistics (NCHS) reference data ${ }^{12}$. Underweight was calculated by Zscore using the NCHS reference values of weightfor-age. Z-scores were calculated using the formula: Z-score $=(\mathrm{X}-$ Median of NCHS $) /$ Standard deviation of NCHS, where $\mathrm{X}$ is an individual value. Weight-for-age Z-score (WAZ) was calculated and WAZ $<-2$ taken as underweight. Severity of underweight was assessed by categorising severity of malnutrition by percentage prevalence ranges recommended by $\mathrm{WHO}^{13}$. The severity condition of the population depends on the prevalence of underweight viz. low, medium, high and very high when the prevalence of underweight among the infants were $<10 \%, 10$ $19 \%, 20-29 \%$ and $\geq 30 \%$ respectively ${ }^{13}$.

Ethical issues: The study was approved by the Institutional Board of Ethics, Midnapore Medical College and Hospital, Midnapore, India on 04 January 2016. The necessary permission for carrying out this study was also obtained from the administrative authority of the district. Written informed consent was taken from the respective mothers of the infants before conducting the study.

Statistical analysis: Data were analysed using SPSS for Windows version 16. Data were presented as number (percentage) or mean $\pm \mathrm{SD}$ as appropriate. Student's t-tests were done to study the difference in weight among the boys and girls. Chi square tests were done to find out the association between gender and nutritional status. Odds ratio was done to study the sexual dimorphism in underweight. Binary regression analysis was performed to study the effect of gender and birth weight (LBW/NBW) on the prevalence of underweight among the infants at the age of twelve months.

\section{Results}

Of the initial sample size of 170, two children expired and 4 children were lost to follow up during the study period. Thus, the final sample size was 164. The descriptive statistics of the growth pattern in respect to weight $(\mathrm{kg})$ of the infants $(0-$ 12 months) are presented in Table 1.

Table 1: Descriptive statistics of growth pattern in infants in respect to weight (kg)

\begin{tabular}{|c|c|c|c|}
\hline \multirow{2}{*}{ Age in months } & \multicolumn{2}{|c|}{ Weight (kg) of the infants } & \multirow{2}{*}{ Weight (kg) increment } \\
\cline { 2 - 3 } & Mean \pm Standard deviation & 95\% confidence interval & \\
\hline Birth & $2.72 \pm 0.38$ & $2.66-2.78$ & $0.83 \pm 0.41$ \\
\hline 1 & $3.55 \pm 0.53$ & $3.46-3.63$ & $0.75 \pm 0.59$ \\
\hline 2 & $4.30 \pm 0.81$ & $4.17-4.42$ & $0.70 \pm 0.61$ \\
\hline 3 & $5.00 \pm 0.74$ & $4.88-5.11$ & $0.62 \pm 0.29$ \\
\hline 4 & $5.62 \pm 0.75$ & $5.50-5.73$ & $0.52 \pm 0.27$ \\
\hline 5 & $6.13 \pm 0.75$ & $6.02-6.25$ & $0.41 \pm 0.23$ \\
\hline 6 & $6.55 \pm 0.78$ & $6.43-6.67$ & $0.36 \pm 0.38$ \\
\hline 7 & $6.90 \pm 0.82$ & $6.78-7.03$ & $0.32 \pm 0.37$ \\
\hline 8 & $7.22 \pm 0.82$ & $7.10-7.35$ & $0.27 \pm 0.17$ \\
\hline 9 & $7.50 \pm 0.88$ & $7.36-7.63$ & $0.27 \pm 0.22$ \\
\hline 10 & $7.76 \pm 0.89$ & $7.63-7.90$ & $0.24 \pm 0.23$ \\
\hline 11 & $8.00 \pm 0.88$ & $7.87-8.14$ & $0.23 \pm 0.27$ \\
\hline 12 & $8.23 \pm 0.90$ & $8.09-8.37$ & \\
\hline
\end{tabular}


The maximum and minimum weight gain was noted in the age of $0-1$ months $(0.83 \mathrm{~kg})$ and $11-12$ months $(0.23 \mathrm{~kg})$ respectively. Prevalence of underweight in different periods during the first year of life are presented in Figure 1.

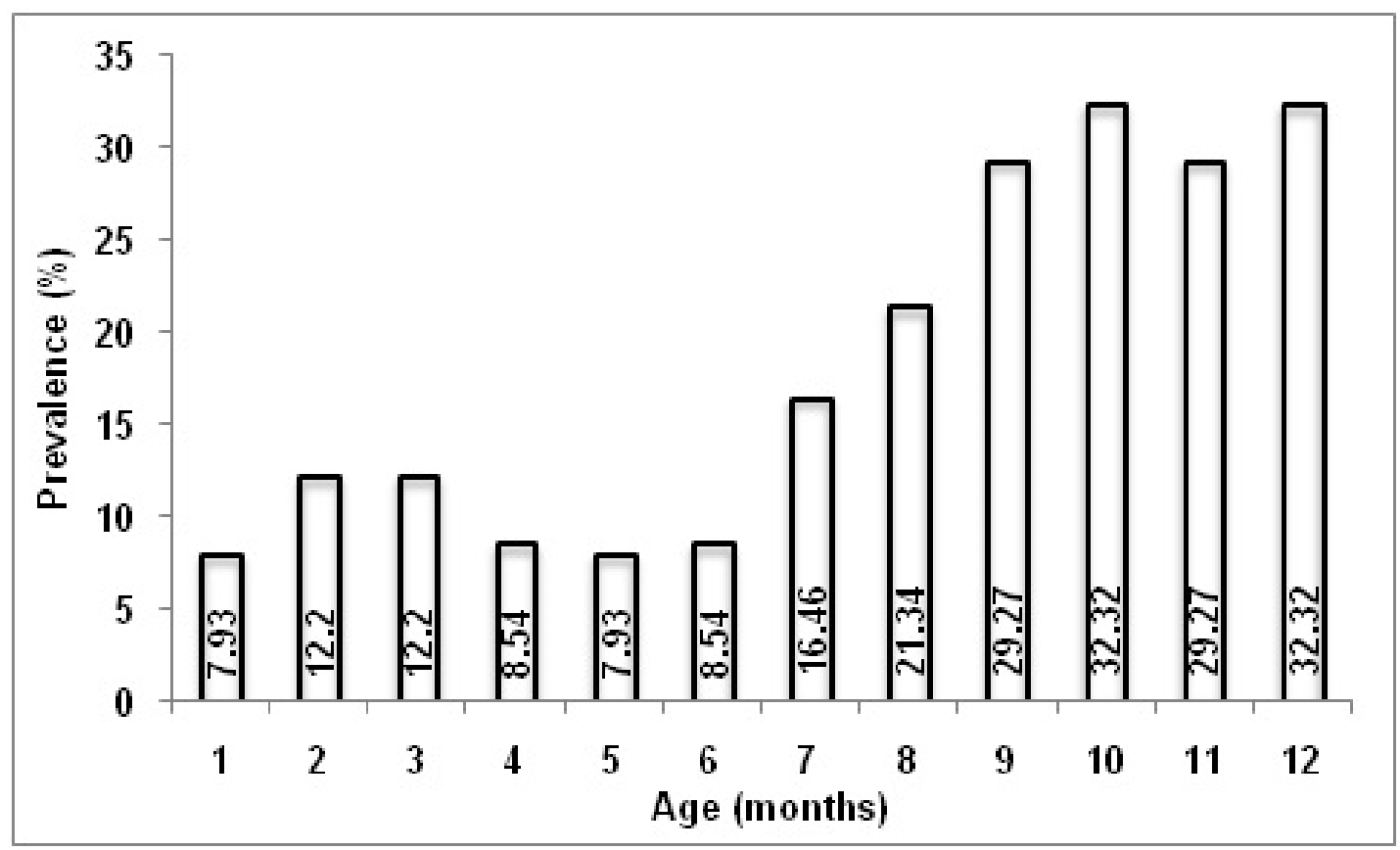

Figure 1: Prevalence of underweight in different periods during infancy

This study showed that the pattern of prevalence of underweight among the infants was changing with the time period. This prevalence of underweight was lower when the infants were in first month and fifth month and after the age of eight months the prevalence of underweight became higher. Impact of sexual dimorphism in growth pattern in respect to weight $(\mathrm{kg})$ of the infants (0-12 months) is presented in table 2 .

Table 2: Impact of sexual dimorphism in growth pattern in respect to weight (kg) among infants

\begin{tabular}{|c|c|c|c|}
\hline Age in months & Girls $(\boldsymbol{n}=\mathbf{8 4})$ & Boys $(\boldsymbol{n}=\mathbf{8 0})$ & t-test \\
\hline Birth & $2.74 \pm 0.42$ & $2.70 \pm 0.33$ & 0.638 \\
\hline 1 & $3.49 \pm 0.58$ & $3.60 \pm 0.46$ & 1.364 \\
\hline 2 & $4.18 \pm 0.71$ & $4.42 \pm 0.90$ & 2.906 \\
\hline 3 & $4.87 \pm 0.79$ & $5.13 \pm 0.67$ & $2.348^{*}$ \\
\hline 4 & $5.48 \pm 0.77$ & $5.76 \pm 0.70$ & $2.338^{*}$ \\
\hline 5 & $6.00 \pm 0.78$ & $6.27 \pm 0.70$ & $2.444^{*}$ \\
\hline 6 & $6.40 \pm 0.80$ & $6.70 \pm 0.72$ & $2.474^{*}$ \\
\hline 7 & $6.75 \pm 0.83$ & $7.06 \pm 0.79$ & $2.562^{*}$ \\
\hline 8 & $7.06 \pm 0.84$ & $7.39 \pm 0.78$ & $2.033^{*}$ \\
\hline 10 & $7.36 \pm 0.90$ & $7.64 \pm 0.83$ & $2.042^{*}$ \\
\hline 11 & $7.63 \pm 0.90$ & $7.91 \pm 0.86$ & $2.294^{*}$ \\
\hline 12 & $7.85 \pm 0.89$ & $8.16 \pm 0.84$ & $2.167^{*}$ \\
\hline
\end{tabular}

Significance level at $*_{p}<0.05$

This study indicated that up to the age of two months, there was no significant difference in the weights among boys and girls but from the age of 3 months, boys were found to be significantly heavier than girls. Impact of sexual dimorphism in prevalence of underweight among the infants (0-12 months) are presented in table 3. 
Table 3: Impact of sexual dimorphism in prevalence of underweight among the infants

\begin{tabular}{|c|c|c|c|}
\hline \multirow{2}{*}{ Age in months } & \multicolumn{2}{|c|}{ Prevalence of underweight } & \multirow{2}{*}{$\boldsymbol{\chi}^{\mathbf{2}}$ test } \\
\cline { 2 - 3 } & Girls (n=84) & Boys (n=80) & 0.920 \\
\hline 1 & $05(05.95)$ & $08(10.00)$ & 3.215 \\
\hline 2 & $14(16.67)$ & $06(07.50)$ & $5.156^{*}$ \\
\hline 3 & $15(17.86)$ & $05(06.25)$ & 0.009 \\
\hline 4 & $07(08.33)$ & $07(08.75)$ & 0.920 \\
\hline 5 & $05(05.95)$ & $08(10.00)$ & 0.009 \\
\hline 6 & $07(08.33)$ & $07(08.75)$ & 0.005 \\
\hline 7 & $14(16.67)$ & $13(16.25)$ & 0.125 \\
\hline 8 & $17(20.24)$ & $18(22.50)$ & 3.678 \\
\hline 9 & $19(22.62)$ & $29(36.25)$ & $9.334^{* *}$ \\
\hline 10 & $18(21.43)$ & $35(43.75)$ & 3.678 \\
\hline 12 & $19(22.62)$ & $29(36.25)$ & $4.215^{*}$ \\
\hline
\end{tabular}

Significance level at ${ }^{*} p<0.05 ; * * p<0.01$

This study indicated that the boys were more nutritionally vulnerable in the rural communities in comparison to girls. Significant differences in the prevalence of underweight among the boys and girls were noted at the ages of 3,10 and 12 months, More boys at 3 months were underweight than the girls. The comparison in the weights of the LBW and normal birth weight (NBW) babies in different ages is presented in Figure 2. The Box and Whisker plots depict that the mean weight of the NBW babies were higher than the LBW babies in all ages.

Growth pattern in respect to weight of LBW babies in comparison with NBW babies are presented in Figure 3.

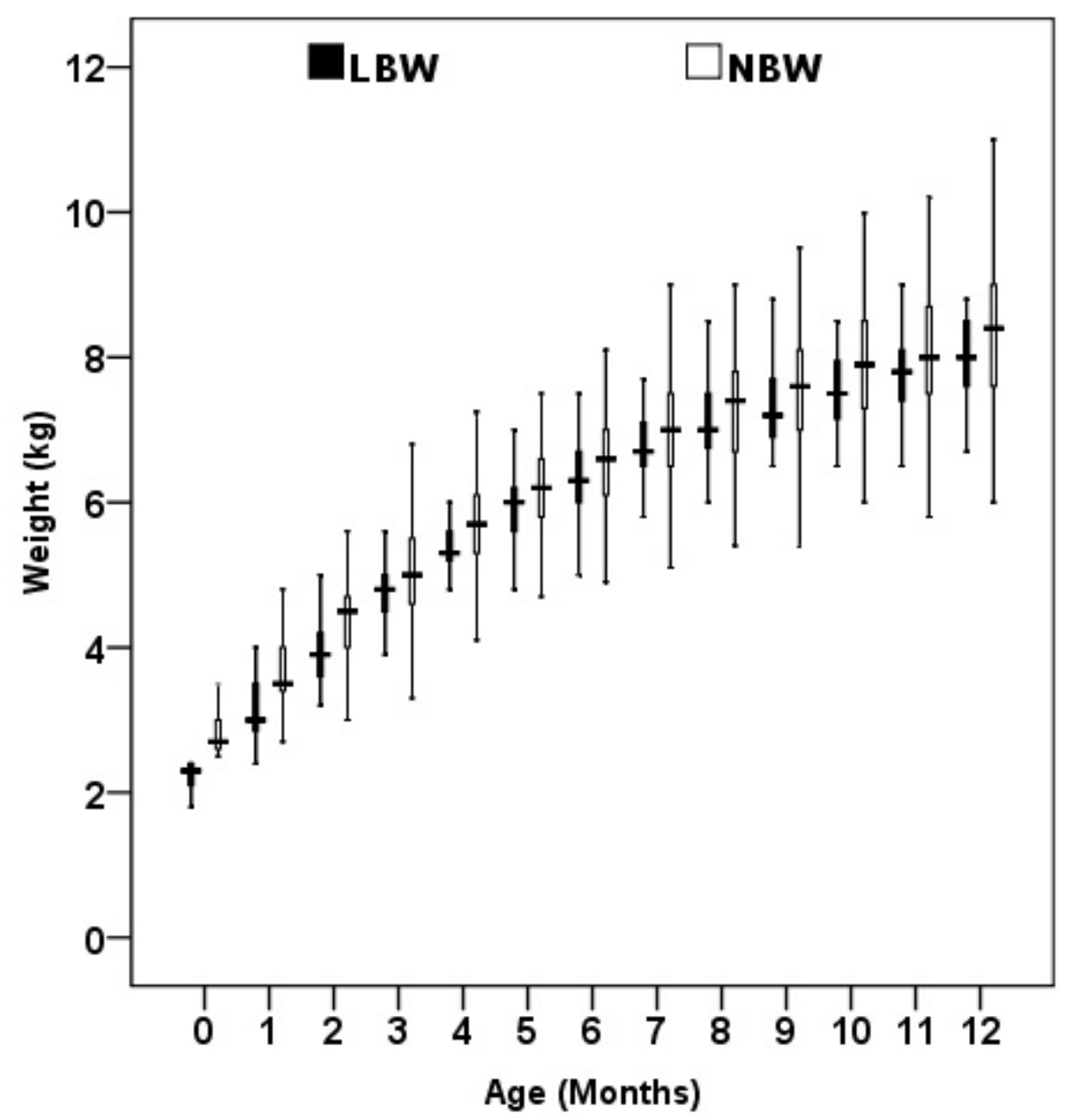

Figure 2: Comparison of weights of the $L B W$ and $N B W$ babies at different ages 


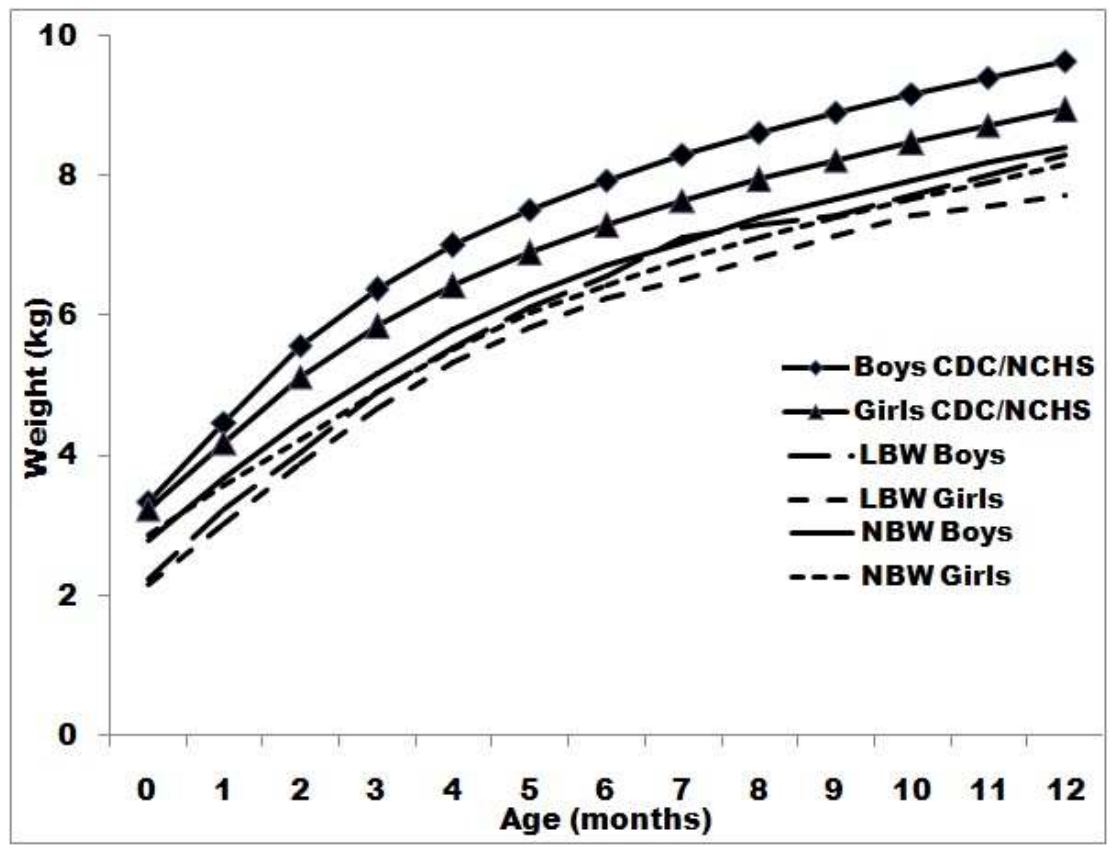

Figure 3: Growth pattern in respect to weight of low birth weight babies

While studying the growth pattern among the LBW children, it was noted that these children had lower weight in all the ages compared to their normal counterparts, except the LBW boys at the age of seven months. But the student t-test showed that there was significant difference only in the weight of the LBW and NBW in the age up to 2 months. This study also indicated that the LBW boys had better catch up growth in comparison to that of the girls. However, it should be noted that all the children studied in this locality were far away from the international standard.

Impact of birth weight on the growth pattern in respect to weight $(\mathrm{kg})$ among the infants (0-12 months) are presented in table 4.

Table 4: Impact of birth weight on the growth pattern in respect to weight (kg) among the infants

\begin{tabular}{|c|c|c|c|c|}
\hline \multirow[t]{2}{*}{ Age in months } & $<2.50 \mathrm{~kg}$ & $2.50-2.99 \mathrm{~kg}$ & $\geq 3.00 \mathrm{~kg}$ & \multirow[t]{2}{*}{ ANOVA } \\
\hline & $n=27$ & $n=88$ & $n=49$ & \\
\hline Birth & $2.21 \pm 0.23$ & $2.63 \pm 0.12$ & $3.16 \pm 0.25$ & $250.376 * * *$ \\
\hline 1 & $3.12 \pm 0.44$ & $3.43 \pm 0.43$ & $3.99 \pm 0.43$ & $42.418 * * *$ \\
\hline 2 & $3.96 \pm 0.45$ & $4.15 \pm 0.76$ & $4.75 \pm 0.88$ & $12.880 * * *$ \\
\hline 3 & $4.78 \pm 0.45$ & $4.83 \pm 0.74$ & $5.42 \pm 0.71$ & $12.946 * * *$ \\
\hline 4 & $5.44 \pm 0.50$ & $5.48 \pm 0.75$ & $5.96 \pm 0.75$ & $7.907 * * *$ \\
\hline 5 & $5.98 \pm 0.59$ & $5.98 \pm 0.77$ & $6.50 \pm 0.68$ & $8.920 * * *$ \\
\hline 6 & $6.40 \pm 0.62$ & $6.40 \pm 0.81$ & $6.90 \pm 0.69$ & $7.762 * * *$ \\
\hline 7 & $6.81 \pm 0.84$ & $6.76 \pm 0.85$ & $7.20 \pm 0.71$ & $4.784 * *$ \\
\hline 8 & $7.06 \pm 0.73$ & $7.10 \pm 0.84$ & $7.53 \pm 0.78$ & $5.022 * *$ \\
\hline 9 & $7.29 \pm 0.76$ & $7.38 \pm 0.90$ & $7.81 \pm 0.82$ & $4.986 * *$ \\
\hline 10 & $7.58 \pm 0.77$ & $7.66 \pm 0.92$ & $8.06 \pm 0.83$ & $4.135^{*}$ \\
\hline 11 & $7.79 \pm 0.77$ & $7.91 \pm 0.93$ & $8.30 \pm 0.79$ & $4.255^{*}$ \\
\hline 12 & $7.99 \pm 0.79$ & $8.17 \pm 0.97$ & $8.48 \pm 0.79$ & $3.156^{*}$ \\
\hline
\end{tabular}

Significance level at $* p<0.05 ; * * p<0.01 ; * * * p<0.001$

In all the ages there is a significant difference in the weight of the children. The children with the birth weight of $\geq 3.00 \mathrm{~kg}$ had a higher weight in all ages compared to the other two groups.
Impact of birth weight on the prevalence of underweight among the children (0-12 months) are presented in Figure 4. 


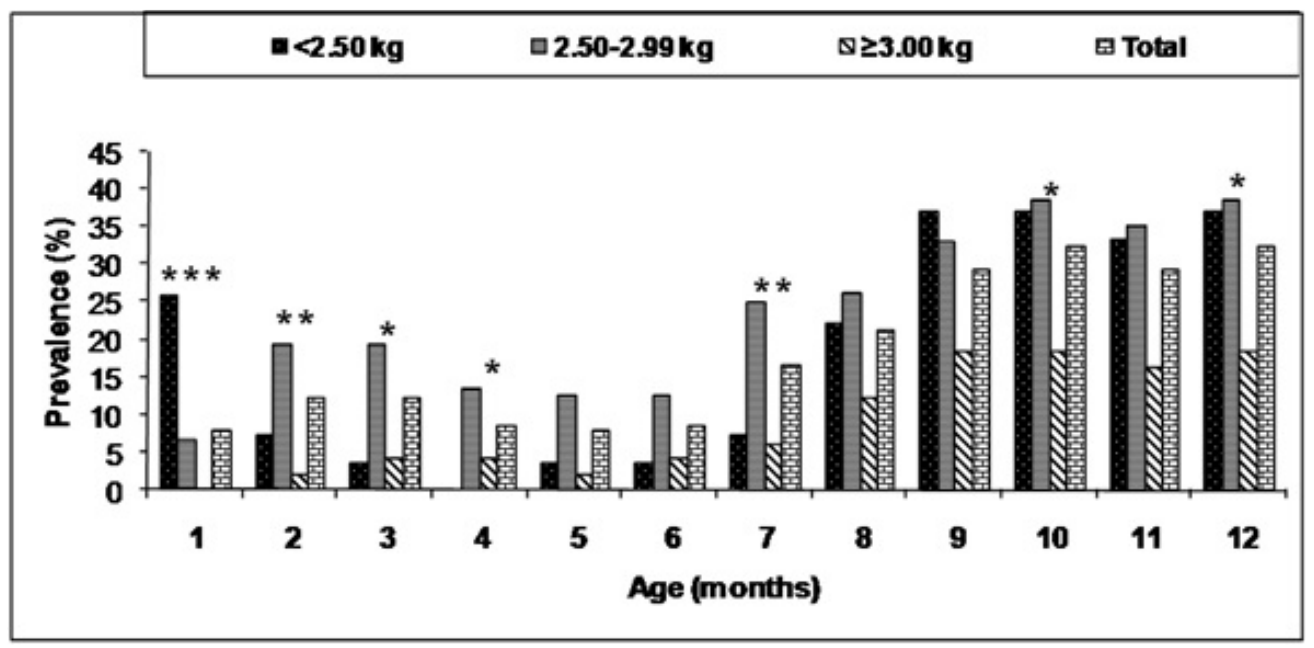

Figure 4: Impact of birth weight on the prevalence of underweight among the infants Statistical significance level at $* p<0.05 ; * * p<0.01 ; * * * p<0.001$ while comparing the three groups according to birth weight viz. $<2.50 \mathrm{~kg}, 2.50-2.99 \mathrm{~kg}$, and $\geq 3.00 \mathrm{~kg}$

The difference in the prevalence of underweight was noted at the age of 1, 2, 3, 7, 10 and 12 months while comparing the prevalence of underweight among the three groups according to birth weight viz. $<2.50 \mathrm{~kg}, 2.50-2.99 \mathrm{~kg}$, and $\geq 3.00 \mathrm{~kg}$.

This study indicated that the prevalence of underweight was significantly higher among the male infants than the female infants at the age of the $12^{\text {th }}$ month. While, we study the effect of birth weight (LBW/NBW) on the prevalence of underweight of the infants at the age of $12^{\text {th }}$ month, indicated that LBW babies were 1.286 time more likely to be underweight at this age (data not shown). Furthermore, binary regression analysis showed a significant relationship with underweight and gender (Wald=4.178; $\mathrm{P}<0.05$ ), but no such association was found underweight and birth weight (Wald=0.351; $\mathrm{P}>0.05$ ) (data not shown).

\section{Discussion}

The weight-gain patterns of the infants were agespecific and nonlinear during the first year of life when measured at frequent intervals (Table 1). The similar patterns of weight gain during infancy were noticed in previous studies ${ }^{14,15}$. During this one year longitudinal study on the weight of the infants, the average increase of weight was $0.46 \mathrm{~kg}$ per month. In a similar study conducted in Bangladesh, Karim and Mascie-Taylor ${ }^{16}$ reported that the average increase of weight per month was $0.44 \mathrm{~kg}$. In the present study, we found that the highest mean rate of growth in respect to weight occurred during the first month $(0.83 \pm 0.41 \mathrm{~kg})$ and the lowest was between 11 and 12 months $(0.23 \pm 0.27 \mathrm{~kg})$. While, Karim and Mascie-Taylor ${ }^{16}$ in their study found that the highest and lowest mean rate of growth in respect to weight were in the first month $(1.03 \mathrm{~kg})$ and between 9 and 10 months $(0.16 \mathrm{~kg})$ respectively. In our study prevalence of underweight was very much less in the infants when they were 1, 4, 5 and 6 months old (Figure $1)$. However, when the children reached the age of 8 months, the prevalence of underweight was in the 'high' category according to categorisation of severity of malnutrition by percentage prevalence ranges given by WHO guideline ${ }^{13}$. The situation has become worse after that period, the children during the period of 9 to 12 months were either in the critically suffering from the undernutrition and the situation was 'very high' category of underweight according to $\mathrm{WHO}^{13}$ or in just the borderline to enter into this severe condition. There may be several factors responsible for such high prevalence of underweight among the children in this locality. The faulty breastfeeding practices and improper weaning may be responsible for wide spread prevalence of undernutrition among infants of the rural areas ${ }^{17}$. The recent report of the fourth National Family Health Study carried out from 2015-2016 in India found that the only 42.2\% children at the age group of 6-8 months got complementary feeding and this situation was little better when the children reached the age group of 9-11 months and $12-17$ months with the $62.3 \%$ and $69.8 \%$ respectively received complementary feeding 9 . In this report, it was also documented that the practice of exclusive breastfeeding below 6 months was only $55.0 \%$ in India 9 . This poor quality of feeding drastically affected the nutritional status of the infants. In another study in the rural areas of Paschim Medinipur District, we found that 37.50\% of the children were given some kind of pre-lacteal feeding and only $61.45 \%$ of the children were exclusive breastfed till 6 months of age $^{6}$. Viyayalakshmi et al. ${ }^{18}$ stated that pre-lacteal feeding is associated with diarrhoea in the newborn and this may be also responsible for growth faltering in the later months. 
There was no difference in the sexual dimorphism in the birth weight as described in the previous studies $^{14,19}$. Lampl et al ${ }^{14}$ found a significant gender difference in the birth weights but by the $10^{\text {th }}$ day this gender difference in the weight of the infants was not evident but it re-emerged at 2 months of age and continued across the first year. In a similar study, conducted by Lahiri and Chakraborty ${ }^{19}$ in rural areas of West Bengal, showed that the weights of the male infants were comparatively higher than the female infants in every month. In our study, we found that gender difference in weight of the infants started at 3 month and continued across the first year. Hormonal status and body composition is different for males and females. Growth signalling cascade among males and females is being more influenced by sex hormonal status ${ }^{20}$. Normal growth rate pattern is noticed in newborn from birth, reflects intact growth hormone (GH) pathways ${ }^{21,22}$. GH concentration is different among male and females even in neonatal period ${ }^{23}$. Body composition, linear growth, weight gain is being influenced by $\mathrm{GH}$ pulsatility pattern, which is different in males and females. GH pulse pattern of low troughs and high peaks, characteristic of male is responsible for higher growth rate in boys ${ }^{24}$. Irregular GH pulse pattern of high troughs and low peaks is characteristic of females. Similarly, irregular GH pulsatility is noticed in slowly growing children ${ }^{25}$. Sex differences in GH pulsatility influences metabolic processes in liver ${ }^{24}$ and thus it affects the rate of growth through downstream hormonal effects $^{26}$. This study also found that the prevalence of underweight among boys in the age of 9 months to 12 months was more than $30 \%$ (Table 3). According to the categorisation of severity of malnutrition by percentage prevalence ranges given by $\mathrm{WHO}^{13}$, the prevalence of underweight among the boys were 'very high' whereas the girls were in 'high' category of underweight by showing the prevalence of underweight from $21.43 \%$ to $25.00 \%$ during the said ages (Table 3 ). The Odds ratio indicated that the boys were $1.945,2.852,1.945$, 2.000 times more prone to become underweight than the girls when they were in 9, 10, 11, 12 months respectively. Even though a strong preference for the male child exists in a typical Indian society, underweight is much more common among boys. Possible explanation can be the continuation of exclusive breast feeding in boys up to 9 months, when breast milk is insufficient to meet the nutritional needs of infants ${ }^{17}$. Since preference for male child is high, mothers used to take the male child to the kitchen during cooking, thus exposing him to air pollution ${ }^{27}$ and this may be responsible for acute respiratory infections (ARI) and other health complications. Several studies documented that the cooking smoke induced ARI were more common among the boys than the $\operatorname{girls}^{28-30}$. Some earlier studies noted that there was a difference in feeding practices among boys and girls in the society that may be a significant factor affecting growth pattern ${ }^{31,32}$. Popkin ${ }^{32}$ noticed the early introduction of complementary feeding among boys in comparison to girls and the greater quantities of complementary food being provided to boys. This too-early introduction of complementary feeding among the boys also has a negative impact on boys ${ }^{31}$.

In this study the incidence of LBW was $16.5 \%$ (Table 4). The recent report of the fourth National Family Health Study (NFHS-4) ${ }^{9}$ found that the incidence of LBW was $18.2 \%$ in India as a whole, while in West Bengal state of India, the incidence of LBW was $16.7 \%$. The birth weight of the neonate has both short term and long term impact on the growth pattern. To study impact of the birth weight on the growth pattern, the infants were categorized into three groups based on birth weight viz. $<2.50 \mathrm{~kg}, 2.50-2.99 \mathrm{~kg}$ and $\geq 3.00 \mathrm{~kg}$. The mean birth weights of these three groups were $2.21 \mathrm{~kg}$, $2.63 \mathrm{~kg}$ and $3.16 \mathrm{~kg}$ respectively. After one year the weights of these three groups were $7.99 \mathrm{~kg}, 8.17 \mathrm{~kg}$ and $8.43 \mathrm{~kg}$ respectively. This data is comparable to the previous study conducted by Banik et al. ${ }^{33}$. This is suggested that the weight of the infants both during birth and at 12 months as documented by Banik et al. $^{33}$ were less than the weight of the infants during the said time period in our study. If we calculate the weight increment in terms of one year, we found that it was maximum in $<2.50$ group (2.61 times) and minimum in $\geq 3.00 \mathrm{~kg}$ ( 1.68 times). Similar result were noted in the previous study where maximum increment was noted in $<2.50$ group (2.30 times) and minimum in $\geq 3.00 \mathrm{~kg}$ (1.44 times). It indicated that the lower the weight higher the tendency of catch up growth though it could not touch the same level at the end of 12 months. This may be due to the tiniest and most immature babies having late and poor catch up growth $^{34}$ and the morbidities like diarrhoea and respiratory infections were higher in LBW babies ${ }^{35}$.

While comparing the prevalence of underweight at 12 months among the LBW and NBW infants, it was observed that the prevalence of the said parameter of the two groups were $37.04 \%$ and $31.39 \%$ respectively. This indicated that LBW babies are 1.3 times higher chances of being underweight than NBW babies when they were at 12 months $(\mathrm{OR}=1.286,0.544-3.040 ; \mathrm{RR}=1.232$, 0.606-2.504). Rahman et al. ${ }^{36}$ when examining the relationship between LBW and undernutrition utilising data from the Bangladesh Demographic and Health Survey 2011, found that at 12 months of age the prevalence of underweight among the LBW and NBW infants were $36.1 \%$ and $17.0 \%$ respectively. In another study, Medhin et al. ${ }^{37}$ 
found the prevalence of underweight among the LBW and NBW infants when they reached 12 month were $51.1 \%$ and $20.4 \%$ respectively. This study suggests that LBW was a significant predictor of underweight at twelve months of age. Interestingly, this study focused that at 12 months the highest prevalence of underweight was observed among the infants with birth weight 2.50 $2.99 \mathrm{~kg}(38.64 \%)$ not the infants of low birth weight $(37.04 \%)$. While, the prevalence of underweight at 12 months among the infants with birth weight $\geq 3.00 \mathrm{~kg}$ was only $18.37 \%$ and was significantly different than other two groups $\left(\chi^{2}=6.241 ; \mathrm{P}<0.05\right)$. This is reflected in the binary regression analysis, which suggests that the sex of the neonate (Wald=4.178; $\mathrm{P}<0.05$ ) was the more important predictor of underweight at twelve months of age than the birth weight (Wald $=0.351 ; \mathrm{P}>0.05$ ). This study suggests the need for further research on the growth pattern among the different population in this locality especially among the tribal population and also more in-depth longitudinal study is needed to the study the factors affecting catch up growth of the LBW babies.

\section{Conclusions}

This longitudinal study on the weight pattern of the infants up to 12 months of age suggests that the male infants are likely to be underweight when they are nine months of age.

\section{Acknowledgements}

Authors are thankful to Dr. Jayasree Laha, Principal, Raja Narendra Lal Khan Women's College, Midnapore, West Bengal, India and Dr. Panchanan Kundu, Principal, Midnapore Medical College, Midnapore, West Bengal, India for their constant encouragement throughout the study. The authors are also thankful to the mothers/care givers of the infants for their kind co-operation during the investigation.

\section{References}

1. Lechtig A, Delgado $\mathrm{H}$, Martorell R, Yarbrough C, Klein RE. Materno-fetal nutrition. In: Jelliffe DB, Jelliffe EFP, Editors. Human Nutrition: A Comprehensive Treatise. New York: Plenum Press. Vol 11. 1979. pp. 79-127. https://doi.org/10.1007/978-1-4613-29169_6

2. Hashim Z. Pattern of growth in weight and length among urban Malaysian infants. International Journal of Food Sciences and Nutrition 1992; 43:79-87. https://doi.org/10.3109/096374892090275 35
3. Roy SK, Maiti S, Sinha NK, Mandal K. Maternal body-mass-index and several socioeconomic factors predict gestational duration and birth weight: A crosssectional study from India. Cell Biology Research and Therapy 2015; 4:1. https://doi.org/10.4172/23249293.100011 5

4. Sinha NK, Maiti K, Samanta P, Das DC, Banerjee P. Nutritional status of 2-6 year old children of Kankabati Grampanchayat, Paschim Medinipur district, West Bengal, India. Sri Lanka Journal of Child Health. 2012; 41(2):60-4.

https://doi.org/10.4038/sljch.v41i2.4392

5. Sinha NK, Maiti S. Prevalence of undernutrition among unprivileged preschool children (2-6 years) of Midnapore town, India. Malaysian Journal of Paediatrics and Child Health. 2012; 18(1): 58-69.

6. Sinha, N.K., Das, D.C., Maiti, S., Chakraborty, S. Breastfeeding knowledge, attitude and practice among tribal mothers: A community-based study from rural areas of Paschim Medinipur District. International Congress on Global Innovation and Research in Education, Sports and Yoga (GIRESSY: 2017). Delhi: Akinik Publications. 2017; IV. pp 526-33.

7. Sarkar A, Samanta M, Sinha NK, Samanta P, Das S, Bose K. A longitudinal study of weight gain among Santal and Non-Santal infants of Kankabati Grampanchayat, West Bengal, India. Indian Journal of Biological Sciences. 2010; 16:29-33.

8. Sinha NK, Das S, Bose K, Nandi DK. A longitudinal growth study of weight among Lodha and Non-Lodha infants and young children of Lodhasuli, West Bengal, India. Antrocom 2010; 6(2):53-62. https://doi.org/10.31826/9781463233983023

9. International Institute for Population Sciences (IIPS) and ICF. National Family Health Survey (NFHS-4), 2015-16: India. Mumbai: IIPS. 2017.

10. Bisai S, Mallick C. Prevalence of undernutrition among Kora-Mudi children aged 2-13 years in Paschim Medinipur District, West Bengal, India. World Journal of Pediatrics 2011; 7(1); 31-6. 
https://doi.org/10.1007/s12519-010-02393

PMid: 21086088

11. Lee RD, Nieman DC. Nutritional assessment. 3rd ed. New York: McGraw Hill. 2003.

12. World Health Organization. Measuring changes in nutritional status. Geneva: World Health Organization. 1983.

13. World Health Organization. Physical Status: The use and Interpretation of Anthropometry. Technical report Series no. 854. Geneva: World Health Organization. 1995.

14. Lampl M, Thompson AL, Frongillo EA. Sex differences in the relationships among weight gain, subcutaneous skinfold tissue and saltatory length growth spurts in infancy. Pediatric Research. 2005; 58(6): $1238-42$.

https://doi.org/10.1203/01.pdr.000018432

7.65102.a6

PMid: 16306200

15. Giani U, Filosa A, Causa P. A non-linear model of growth in the first year of life. Acta Paediatrica 1996; 85:7-13. https://doi.org/10.1111/j.16512227.1996.t b13882.x

PMid: 8834972

16. Karim E, Mascie-Taylor CGN. Longitudinal growth of Bangladeshi infants during the first year of life. Annals of Human Biology 2001; 28(1):51-67. https://doi.org/10.1080/030144601502018 87

PMid: 11201331

17. Mishra V, Roy TK, Retherford RD. Sex differentials in childhood feeding, health care, and nutritional status in India. Population and Development Review 2004; 30(2): 269-95.

https://doi.org/10.1111/j.17284457.2004.0 $131 . x$

18. Vijayalakshmi S, Patil R, Datta SS, Narayan KA, Stephen F. Feeding practices and morbidity pattern of infants in a rural area of Puducherry - A follow up study. Journal of Community Medicine and Health Education 2014; 4: 304. https://doi.org/10.4172/21610711.100030

4

19. Lahiri A, Chakraborty A. Predictors of weight velocity in the first 6 months of life in a rural block of West Bengal: A longitudinal study. The Indian Journal of Community Medicine 2019; 44:92-6.

20. Garnett SP, Hogler W, Blades B, Baur LA, Peat J, Lee J, et al. Relation between hormones and body composition, including bone, in pre-pubertal children. American Journal of Clinical Nutrition. 2004; 80:966-72.

https://doi.org/10.1093/ajcn/80.4.966

PMid: 15447907

21. Wit JM, Van Unen H. Growth of infants with neonatal growth hormone deficiency. Archives of Disease in Childhood 1992; 67:920-4.

https://doi.org/10.1136/adc.67.7.920

PMid: 1519958 PMCid: PMC1793852

22. Pena-Almazan S, Buchlis J, Miller S, Shine B, MacGillivray M. Linear growth characteristics of congenitally GHdeficient infants from birth to one year of age. Journal of Clinical Endocrinology \& Metabolism 2001; 86:5691-4.

https://doi.org/10.1136/adc.67.7.920

PMid: 1519958 PMCid: PMC1793852

23. Geary MP, Pringle PJ, Rodeck $\mathrm{CH}$, Kingdom JC, Hindmarsh PC. Sexual dimorphism in the growth hormone and insulin-like growth factor axis at birth. Journal of Clinical Endocrinology and Metabolism 2003; 88:3708-14.

https://doi.org/10.1210/jc.2002-022006

PMid: 12915659

24. Udy GB, Towers RP, Snell RG, Wilkins RJ, Park SH, Ram PA, et al. Requirement of STAT5b for sexual dimorphism of body growth rates and liver gene expression. Proceedings of the National Academy of Sciences of the United States of America 1997; 94:7239-44.

https://doi.org/10.1073/pnas.94.14.7239

PMid: 9207075 PMCid: PMC23803

25. Achermann JC, Brook CG, Robinson IC, Matthews DR, Hindmarsh PC. Peak and trough growth hormone (GH) concentrations influence growth and serum insulin like growth factor-1 (IGF-1) concentrations in short children. Clinical Endocrinology (Oxford) 1999; 50:301-8. 
https://doi.org/10.1111/j.13652265.1999.t b03945.x

PMid: 10435054

26. Hindmarsh PC, Fall CH, Pringle PJ, Osmond C, Brook CG. Peak and trough growth hormone concentrations have different associations with the insulin-like growth factor axis, body composition, and metabolic parameters. Journal of Clinical Endocrinology and Metabolism 1997; 82:2172-6.

https://doi.org/10.1210/jc.82.7.2172

PMid: 9215290

27. Mishra V, Retherford RD, Smith KR. Indoor air pollution: The quiet killer. AsiaPacific Issues 2002; 63: 1-8.

28. Mishra V, Retherford RD. Cooking smoke increases the risk of acute respiratory infection in children. National Family Health Survey Bulletin. 1997; 8: 1-4.

29. Mishra V, Smith KR, Retherford RD. Effects of Cooking Smoke and Environmental Tobacco Smoke on Acute Respiratory Infections in Young Indian Children. Population and Environment 2005; 26(5):375-96. https://doi.org/10.1007/s11111-005-0005y

30. A Mandal S, Zaveri A, Mallick R, Chouhan P. Impact of Domestic Smokes on the Prevalence of Acute Respiratory Infection (ARI) among Under-Five Children: Evidence from India. Children and Youth Services Review. 2020. https://doi.org/10.1016/j.childyouth.2020. 105046

31. Bork KA, Diallo A. Boys are more stunted than girls from early infancy to 3 years of age in rural Senegal. Journal of Nutrition 2017; 147(5):940-7.

https://doi.org/10.3945/jn.116.243246

PMid: 28298540
32. Popkin BM, Adair L, Akin JS, Black RE, Briscoe J, Fleiger W. Breast feeding and diarrheal morbidity. Pediatrics 1990; 86:874-82.

33. Banik ND, Krishna R, Mane SI, Raj L, Taskar AD.A longitudinal study of physical growth of children from birth up to 5 years of age in Delhi. Indian Journal of Medical Research 1970; 58(1):135-42.

34. Sridhar K, Bhat BV, Srinivasan S. Growth pattern of low birth weight babies in the first year of life. Indian Journal of Pediatrics 2002; 69(6):485-8. https://doi.org/10.1007/BF02722649 PMid: 12139133

35. Das BK, Mishra RN, Mishra OP, Bhargava V, Prakash A. Comparative outcome of low birth weight babies. Indian Pediatrics. 1993; 30(1); 15-21.

36. Rahman MS, Howlader T, Masud MS, Rahman ML. Association of low-birth weight with malnutrition in children under five years in Bangladesh: Do mother's education, socio-economic status, and birth interval matter? PLOS ONE 2016; 11(6): 0157814. https://doi.org/10.1371/journal.pone.0157 814

PMid: 27355682 PMCid: PMC4927179

37. Medhin G, Hanlon C, Dewey M, Alem A, Tesfaye F, Worku B, et al. Prevalence and predictors of undernutrition among infants aged six and twelve months in Butajira, Ethiopia: The P-MaMiE Birth Cohort. BMC Public Health 2010; 10(27): 1-15. https://doi.org/10.1186/1471-2458-10-27 PMid: 20089144 PMCid: PMC2826285 